\title{
Effect Of 12 Station Circuit Training On Antopometry Obesity (Case Study)
}

\author{
Y. Touvan Juni Samodra \\ Pendidikan Kepelatihan Olahraga \\ Fakultas Keguruan dan Ilmu Pendidikan \\ ${ }^{1}$ Universitas Tanjungpura, Pontianak, Kalimantan Barat Indonesia \\ Email: tovan@fkip.untan.ac.id
}

\begin{abstract}
Obesity was degenerative issues in the communities. The research gave treatment 12 stations. Two samples, one over weight and obese the othe one. This research applied eksperiment with cirkuit 12 station, three sets and 16 time training. The intensity of training was 75\%. Data analyzed by descriptive statistic. Research showed that the subjek with obese category weight loss $20 \mathrm{~kg}$ and $0.5 \mathrm{~kg}$ for the othe one. Two subjek were reduce in skin fold antropometry measurements (chest, abdomen, thight) also in around abdomen and hip. One subjek hipertropy in thigth Gastronemius and bicep triceps, ones subjek were hypertropi in the bicep tricep. Based on the case concluded, witth $75 \%$ intensity could be reduce weight and skinfold measurements result.
\end{abstract}

Keywords: Fitness, Obesity, Exercise

\section{Studi Kasus Pengaruh Latihan Sirkuit 12 Station Terhadap Antopometri Obesitas}

\begin{abstract}
Abstrak
Obesitas merupakan isu penyakit degenerative yang terus melanda di masyarakat. Penelitian memberikan perlakukan dengan latihan gym 12 station terhadap perubahan penurunan berat badan. Sampel 2 orang yang mengalami obesitas berat dan obesitas awal. Metode penelitian dengan eksperimen memberikan treatment latihan beban dengan metode sirkuit 12 alat tiga set selama 16 kali pertemuan. Intensitas latihan $75 \%$ dari maksimal. Data dianalisis dengan deskriptif statistik. Hasil penelitian menunjukkan bahwa untuk subyek dengan obesitas berat peng mengalami penurunan sampa $20 \mathrm{~kg}$ dan untuk subyek kedua tidak mengalamai penurunan, tetapi terjadi penurunan lingkar bagian yang dilakukan pengukuran. Berdasarkan kasus ini dapat disimpulkan bahwa latihan beban dengan dosis $75 \%$ dapat menurunkan berat badan dan dapat menurunkan lingkar bagian-bagian badan yang diadakan pengukuran.
\end{abstract}

Kata Kunci: Kebugaran, Obesitas, Latihan

Info Artikel

Dikirim

Diterima

Dipublikasikan
: 27 September 2020

: 7 Oktober 2020

: 12 November 2020
C 2020 IKIP BUDI UTOMO MALANG

P-ISSN 2613-9421

E-ISSN 2654-8003

$凶$ Alamat korespondensi: tovan@fkip.untan.ac.id

Universitas Tanjungpura, Jl. Prof. Dr. H. Hadari Nawawi, Bansir Laut, Kec. Pontianak Tenggara, Kota Pontianak,

Kalimantan Barat, 78124 Indonesia 


\section{PENDAHULUAN}

Obesitas menjadi isu Internasional dan tidak terkecuali Indonesia, Obesitas menjadi krisis permasalahan global, hal ini terjadi pada Negara industry Menurut catatan WHO 30-40\%, Eropa 20-30\%, Asia, afrika 10-20\%, dan terus meningkat mulai 1990-2010 meningkat 7\%. Sampai tahun 2020 trend ini diramalkan akan menjadi 60 juta (Wang \& Lim, 2012). Di Mexico 34\% anak dan remaja umur 5-19 tahun mengalami obesitas (Aceves-Martins, Llauradó, Tarro, Solà, \& Giralt, 2016). Obesitas dekat kaitannya dengan kerusakan kardiovaskular. Hal ini menjadi epidemic, dianjurkan penanganannya dengan latihan dengan intensitas moderat. Namum demikian kegiatan seperti berjalan, berdiri dianjurkan sebagai aktivitas jasmani (Villablanca et al., 2015). Sebagi contoh di tahun 2014 dilakukan penelitian di sebuah perguruan tinggi di fakultas kedokteran dan hasilnya mahasiswa kedokteran berdasarkan peneltian memiliki kebugaran yang rendah degan 14 dari 56 masuk dalam ketegori overweight (Zulfiqar, 2014). Kenyataan ini merupakan fenomena yang terjadi dan selalu mengalami peningkatan dari tahun ke tahunnya.

Mengapa hal ini dapat terjadi? Beberapa penelitian memberikan gambaran yang cukup jelas penyebab meningkatnya obesitas ini. Peningkatan kesejahteraan secara global meningkatkan jumlah konsumsi, terutama konsumsi makanan cepat saji, perulaku ini semakin meningkatkan prevalensi penyakit denegeratif seperti diabet tipe 2, jantung dan kanker (Zobel, Hansen, Rossing, \& von Scholten, 2016).

Di Negara yang pendapatannya rendah dan menengah wanita lebih banyak yang mengalami obesitas hal ini disebabkan karena perubahan pola makan, serta upaya untuk menangani permasalahan ini masih sangat terbatas (Ford, Patel, \& Narayan, 2017). Pernyataan lain yang menguatkan dari artikel di tahun sebelumnya, bahwa prevalensi obesitas semakin meningkat dengan berubahnya gaya hidup pada anak-anak dan remaja, latihan dengan intensitas tinggi direkomendasikan untuk menangani hal ini (Dias et al., 2016).

Pada dasarnya obesitas terjadi sebagai puncak proses kelebihan asupan kalori dan kurangnya gerak sebagai usaha untuk membuang kalori yang telah 
masuk. Efek obesitas pada umumnya akan menyebabkan penderita menjadi semakin malas bergerak dan tubuh akan semakin membesar. Kurang bagusnya kemampuan gerak sebagai akibat mengalami kelebihan berat bagi siswa sekolah mengharuskan sekolah untuk mengambil kebijakan yang positif agar memberikan iklim yang positif terhadap keikutsertaan siswa dalam pendidikan jasmani (Maïano et al., 2018). Hasil penelitian ini memberikan bukti bahwa siswa yang mengalami kelebihan berat akan cenderung kurang partisipasinya dalam pendidikan jasmani. Bukti berikutnya menyatakan bahwa orang yang memiliki aktivitas dengan intensitas tinggi akan memberikan pengaruh positif terhadap orang yang mengalami obesitas (Bell et al., 2015). Ada hubungan antara fasilitas olahraga di lingkungan dengan kebiasan tidak beraktivtas anak yang berdampak pada obesitas (Navalpotro et al., 2012)

Lebih lanjut secara psikologi akan malu di masyarakat sosial dan menjadi rendah diri. Tiga penelitian berikut memberikan gambaran proses orang yang mengalami obesitas sehingga menjadi permasalahan secara pribadi dan berbahaya secara psikososial. Penilaian diri sendiri yang berlabel kelebihan berat badan ataupun obesitas sangat berpengaruh terhadap kesehatan mental individu dan menyebabkan depresi (Hilbert et al., 2015) . Terdapat hubungan antara obesity dengan depresi dan kesehatan mental, lebih lanjut dinyatakan bahwa semakin berat badan meningkat dilaporkan semakin melemahkan dalam aktivitas jasmani (Nigatu, Reijneveld, De Jonge, Van Rossum, \& Bültmann, 2016). Hasil penelitian yang sangat mengejutkan memberikan gambaran bahwa remaja yang mengalami kelebihan berat dan obesitas dilaporkan mengalami masalah psikososial dan ada kecenderungan untuk bunuh diri (Van Vuuren et al., 2019). Bukti penelitian ini memberikan gambaran bahwa orang yang telah terstigma obesitas akan berat menjalani hidup dan cenderung tertekan. Jangankan untuk mengikuti aktivitas jasmani seperti olahraga, untuk membuat diri percaya diri sudah menjadi sebuah masalah.

Jika seseorang berat badan semakin bertambah dengan demikian maka surface tubuh juga semakin besar. Hal ini akan semakin memperbesar kebutuhan kalori hanya untuk sekedar mempertahankan hidup. Jangka panjangnya obesitas ini akan berpengaruh terhadap kualitas hidup. Orang yang mengalami obesitas 
berpotensi untuk sakit pada bagian pinggang dan punggung sehingga disarankan untuk melakukan latihan dengan intensitas moderat sampai dengan tinggi (Fernandes, Pinto, Ferreira, \& Lira, 2018). Obesitas juga memiliki resiko penyakit sertaan yang akan memperburuh keadaan penderita diantaranya tekanan darah tinggi, jantung, dan ginjal. Dengan berat badan yang berlebih akan memaksa sistem dalam tubuh bekerja lebih ekstra.

Penelitian kaitan dengan penderita kelebihan berat badan dilacak dari artikel belum banyak yang melakukan. Kesulitan dalam mendapatkan sampel dan kerelaan untuk menjadi sampel penelitian menjadi kendala tersendiri. Sedangkan berdasarkan review penelitian yang ada orang yang mengalami kelebihan berat badan sangat dianjurkan untuk latihan, baik latihan yang sifatnya aktivitas jasmani, ataupun latihan mulai intensitas aerobic sampai intensitas yang tinggi. 12 orang yang mengalami obesitas melakukan latihan aerobic 20 menit ternyata menurunkan stress dengan meningkatnya hormone BDNF (Roh, Cho, \& So, 2017). Latihan menari dapat dipegunakan untuk menurunkan lemak dan meningkatkan kepadatan tulang, dengan latihan selama 36 jam selama 3 bulan (Staiano et al., 2017). Latihan dengan intensitas tinggi di atas $70 \%$ pada orang yang mengalami obesitas dapat meningkatkan kualitas tidur setelah latihan 6 bulan (Quist et al., 2019). Ataupun Perubahan pola makan dan perilaku berolahraga dapat mencegah terjadinya diebet tipe 2. Latihan dengan interval intensitas tinggi sangat efektif (Kirwan, Sacks, \& Nieuwoudt, 2017). Untuk mengurangi resiko tekanan darah disarankan untuk menurunkan berat badan dan pola makan (buah-buahan, sayuran, biji-bijian, polong-polongan, biji-bijian, kacang-kacangan, ikan, dan produk susu serta rendah daging) yang baik (Ndanuko, Tapsell, Charlton, Neale, \& Batterham, 2016).

Beberapa review artikel di atas memberikan petunjuk bahwa orang yang mengalami kelebihan berat badan dapat diatasi dengan mengatur pola hidup terutama makan, dan pola aktivitas, mulai dari aktivitas jasmani sampai latihan yang terprogram intensitasnya. Aktivitas jasmani dapat berupa jalan kaki, berkebun, bersepeda atupun aktivitas yang lain yang menggerakkan tubuh. Aktivitas terprogram dimaksudkan adalah kegiatan olahraga, ke tempat pusat kebugaran dengan program latihan dengan dosis tertentu (ringan, moderat, tinggi). 
Dalam penelitian ini meneliti studi kasus sampel orang yang mengalami kelebihan berat badan dengan intensitas $75 \%$ dari kemampuan maksimal. Penelitian terdahulu dinyatakan bahwa latihan dengan intensitas moderat sampai tinggi pengaruhnya akan lebih efektif. Setidaknya beberapa penelitian berikut meredomendasikan hal teserbut, 12 minggu latihan dengan intensitas tinggi 8595\% efektif untuk meningkatkan kebugaran dibandingkan dengan intensitas moderat (60\%-70\%) sampel penelitian adalah anak umur 7-16 tahun (Dias et al., 2018). Latihan interval moderat (80\%) dan tinggi (100\%) memperbaiki BMI dan kadar lemak tubuh, terjadi penurunan denyut nadi, gula darah (Alahmadi, 2014). Latihan interval training dan latihan interval training intensitas tinggi sama sama dapat menurunkan penderita obesitas secara signifikan latihan dilakukan selama 10 minggu 3 kali perminggu (Wewege, van den Berg, Ward, \& Keech, 2017). Latihan dengan intensitas tinggi lebih hasilnya dibandingkan dengan intensitas rendah dalam upaya menurunkan BMI dan meningkatkan kebugaran kardiorespirasi (Gorostegi-Anduaga et al., 2018).

\section{METODE}

Penelitian eksperimen dengan memberikan treatmet kepada 2 orang usia 29 tahun dan 38 tahun yang mengalami kelebihan berat badan, dengan dosis $75 \%$ dari kemampuan maksimal dengan menggunakan sirkuit latihan beban. Serangkaian pengukuran terhadap tinggi badan, Berat badan, Lingkar lengan atas, lingkar pinggang, lingkar panggul, lingkar paha, lingkar betis, lemak dada, lemak perut, lemak paha. Sampel dengan umur 19 tahun dengan tinggi 169 memili berat $115 \mathrm{~kg}$, dan sampel kedua dengan tinggi 171,5 berat 84,5. Adapun station yang dipergukan adalah leg press, benchpress, standing rowing, pull down, tricep extention, leg curl, calf raise, leg extention, butterfly, sit up, back up, crunch, melakukan latihan 3 set dan 3 kali perminggu di malam hari sampai 16 kali pertemuan.

Prosedur treatment, orang coba melakukan pemanasan dinamis kemudian diikuti prosedur streaching untuk melakukan latihan beban, kemudian melakukan latihan beban 3 set, setiap set 12 station. Antar station istirahat 10-20 detik dan antar set set 3-4 menit. Latihan diakhiri dengan bersepeda statis selama 10 menit 
dan streaching statis.

Data dianalisis dengan menggunakan metode deskriptif sederhana, berkaitan dengan kondisi member dilihat dari BMI, dan proporsi ideal badan berdasarkan kajian kebugaran.

\section{HASIL DAN PEMBAHASAN \\ Hasil Penelitian}

Penelitian dilakukan 3 kali dalam seminggu selama 16 kali pertemuan, terhadap 2 sukarelawan yang dijadikan sampel. Berlatih di lab fitnes Jurusan Ilmu Keolahragaan, Fakultas Keguruan dan Ilmu Pendidikan, Universitas Tanjungpura Pontianak. Berdasarkan pencatatan pengetesan terhadap sampel yang melakukan latihan secara rinci dapat dilihat dalam tabel sebagai berikut:

Tabel 1. Data pengukuran sebelum dan setelah perlakuan

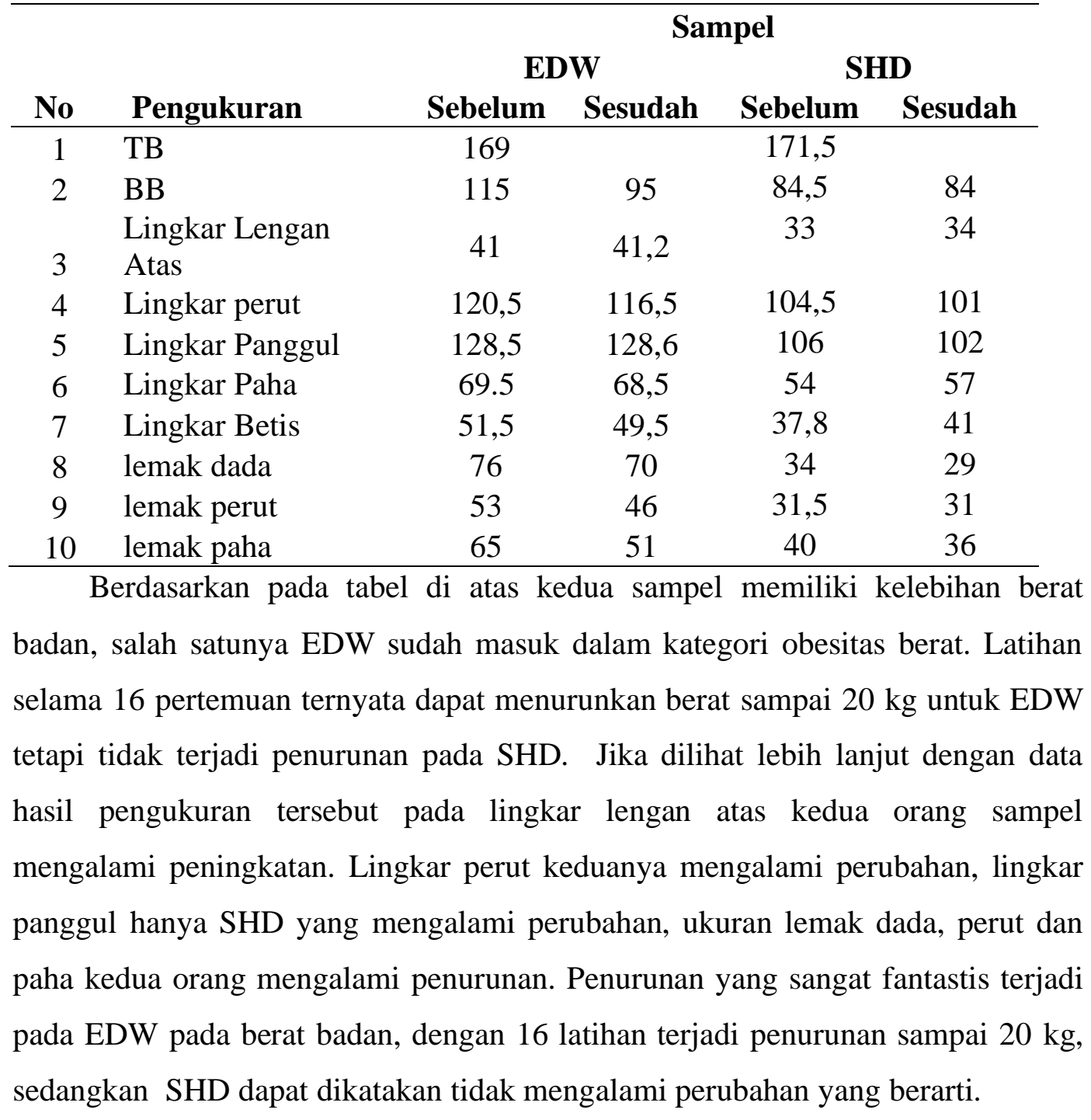


Khusus pada obyek berat badan dapat dikalkulasikan dengan perhitungan dan diringkas dalam tabel 2. Tabel di bawah memberikan informasi patokan berat badan idel, Status berdasarkan perhitungan BMI dan persentase lemak.

Tabel 2. Hasil perhitungan status BMI berdasarkan beberapa kriteria

\begin{tabular}{cccc}
\hline No & Pengukuran & EDW & SHD \\
\hline 1 & TB & 169 & 171,5 \\
2 & BB & 115 & 84,5 \\
3 & Berat ideal & 58.65 & 60.35 \\
4 & Selisih & 56.35 & 24.15 \\
5 & BMI & 40.26 & 28.89 \\
6 & Status atas dasar BMI & Sangat obese & Pre obese \\
7 & Prosentase Lemak & Melebihi norma & 26 \\
\hline
\end{tabular}

Rumus mencari berat badan ideal.

Pehitungan berat badan ideal dalam penelitian ini menggunakan rumus Broca untuk pria: (berat badan - 100) - (10\% x (tinggi badan -100)). Sedangkan status berdasarkan BMI dengan rumus = Berat badan dibagi kuadrat tinggi badan. Berdasarkan pada rumus tersebut maka hasil perhitungan untuk kedua sampel dapat dilihat pada tabel 2. Sedangkan kriteria untuk memutuskan status penyimpangan terhadap ideal berdasarkan BMI adalah sebagai berikut:

Tabel 3. Kreteria berat badan Berdasarkan BMI

\begin{tabular}{ll}
\hline BMI in Adult & Weight Status \\
\hline$<18.5$ & Underweight \\
$18.5-24.9$ & Normal \\
$25.0-29.9$ & Overweight \\
$>30.0$ & obese
\end{tabular}

(Alaa Youssef Ahmed Ahmed Baioumi, 2019)

\section{Pembahasan}

Obesity dan overweight merupakan ancaman bagi Negara berkembang dan ancaman untuk kesehatan publik. Keadaan ini perlu diperhatikan penanganan dini serta antisipasi penyakit penyerta akan harapan hidup meningkat (Vaamonde \& Álvarez-Món, 2020). Di Negara sebesar seperti India, menyusun program untuk hidup aktif yang sehat agar dapat menekan angka obesitas yang tinggi (sampai 
$36.6 \%$ ), dimana efek dari obesitas adalah bahaya penyakit jantung (Ahirwar \& Mondal, 2019). Anak yang mengalami obesitas merupakan permasalahan global, karena status ini akan memperburuk status kesehatan baik jangka pendek ataupun panjang, penyebab kejadian ini adalah salah dalam gaya hidup (Lanigan, Tee, \& Brandreth, 2019). Orang dinyatakan mengalami obesitas jika berat badan di atas 120\% dengan IMT 27 (Cerika, 2011). Berdasarkan pada pendapat ini dapat dinyatakan bahwa kedua orang tersebut dinyatakan mengalami obesitas. Berdasarkan pada (Alaa Youssef Ahmed Ahmed Baioumi, 2019), EDW masuk dalam kategori obese dan SHD masuk dalam kategori overweight. Orang dapat mengalami kelebihan berat badan sampai obesitas dipastikan menjalani pola hidup yang kurang sehat. Asupan kalori lebih besar dibandingkan dengan luaran. Sebuah artikel menjelaskan bahwa obesitas dapat menyebabkan perubahan pada tubuh diantaranya adalah peningkatan reactive oxygen species (ROS) dan hal ini akan menyebabkan stress pada proses oksidasi. Stress oksidasi pada gilirannya akan memicu perubahan mitokondria (disfungsi mitokondria) (de Mello, Costa, Engel, \& Rezin, 2018). ROS akan meningkatkan PH di intraseluler dan hal ini akan memicu produksi radikal bebas. Bahasa yang sederhana radikal bebas ini yang nantinya akan menjadi pemantik sumber penyakit degenerative. Ancaman yang akan dialami oleh penderita obesitas sangat banyak diantaranya resistensi insulin yang akan berakhir pada diabetes militus, dan ternyata obesitas juga dapat menurunkan kemampuan kognisi (Spyridaki, Avgoustinaki, \& Margioris, 2016). Obesitas merupakan pengaruh dari kualitas hidup, sejarah keluarga, makanan, budaya, nutrisi selama kehamilan, histori penyakit, bentuk aktivitas jasmani merupakan hal hal yang menjadi kajian dalam penyumbang obesitas (GonzálezMuniesa et al., 2017). Kaitan dengan hal ini maka pemahaman positif dan berperilaku yang benar kaitannya dengan makanan, pola hidup aktif, pemahaman penyakit turunan dan yang sedang terjadi, sangat menentukan dalam menjaga kesehatan agar terhindar dari obesitas.

Upaya untuk melawan obesitas adalah dengan perilaku hidup sehat, menurunkan asupan kalori dan mempertinggi pengeluaran energi, menurunkan berat badan. Hal ini diperlukan kerjasama antar individu dalam masyarakat (Blüher, 2019). Keluarga, sekolah, dan masyarakat dan pengembangan kebijakan 
harus mendukung upaya hidup sehat dan hidup aktif untuk menangani obesitas pada anak (Dabas \& Seth, 2018).

\section{Upaya Penanganan Obesitas}

Berbagai artikel penelitan memberikan gambaran bahwa penanganan kelebihan berat badan dapat dilakukan dengan setidaknya dua acara yang mudah. Pertama dengan pengaturan pola makan dan dengan latihan. Pengaturan pola makan diantaranya adalah dengan melakukan pembatasan atau pengurangan asupan kalori. Dengan asupan karbohidrat yang rendah akan meningkatkan oksidasi lemak sehingga hal ini akan meningkatkan kinerja daya tahan (Chang, Borer, \& Lin, 2017). Dengan dikurangi asupan kalori maka kinerja yang ada di tubuh secara otomatis akan menyediakan energinya dengan membakar cadangan lemak yang ada. Cara ini diyakinkan dengan bukti penelitian yang menyatakan dengan asupan karbohidrat rendah dan tinggi lemak terbukti meningkatkan daya tahan pada atlet jalan cepat (Chang et al., 2017). Lebih lanjut review penelitian memberikan ringakasan berbagai metode untuk menurunkan berat badan, dengan olahraga, latihan intensitas tinggi, menurunkan asupan kalori serta detoksifikasi. Khusus detox ini sangat efektif menurunkan tetapi juga akan mudah untuk kembali naik (Obert, Pearlman, Obert, \& Chapin, 2017). Ketika penderita kelebihan berat melakukan latihan, terdapat keuntungan lain yaitu Terjadi penurunan resiko diabet dengan melakukan aktivitas jasmani dan diet (Shepherd et al., 2017).

Cara kedua adalah dengan melakukan latihan. Banyak bukti penelitian yang meyakinkan bahwa dengan latihan dengan berbagai cara dapat membantu untuk mengatasi kelebihan berat badan. Latihan meningkatkan luaran jantung dalam memompa darah, dan saat istirahat diperlihatkan bahwa denyut nadi lebih rendah dan terjadi pembesaran jantung (Nystoriak \& Bhatnagar, 2018). Bukti penelitian lain menyatakan bahwa terjadi penurunan resiko diabet terhadap orang yang melakukan aktivitas jasmani dan diet (Shepherd et al., 2017). Apalagi ketika latihan diiringi dengan penataan asupan, sebuah penelitian menyatakan bahwa latihan dan diet sama-sama dapat menurunkan berat badan, diet lebih besar hasilnya dibandingkan dengan latihan (Verheggen et al., 2016). 
Lebih lanjut latihan yang dimaksud diantaranya adalah aktivas jasmani, latihan dengan terprogram intensitasnya (mulai dari rendah, moderat, dan tinggi). Latihan yang dilakukan selama satu tahun memberikan dengan treatment HIIT, RT dan MCT terhadap kontrol Glikemik pada penderita diabet tipe 2. Namum memperbaiki kebugaran dan komposisi tubuh (Magalhães et al., 2019). Latihan dengan intensitas tinggi terhadap penurunan lemak pada wanita yang mengalami obes dengan latihan 10 bulan. Latihan yang dipergunakan adalah sirkuit tranining dengan 10 station. Latihan dapat menurunkan berat badan 6\%, menurunkan lemak tubuh sampai 5\%, menaikkan kekuatan 27,2\%, daya tahan mengalami kenaikan 26,8\%, (Batrakoulis, et al. (Aug 2018). Penelitian lain menyatakan bahwa latihan intensitas tinggi lebih baik untuk meningkatkan kebugaran dan menurunkan lemak tubuh dibandingkan dengan latihan tradisional (Türk et al., 2017). Ternyata kebugaran jasmani berkorelasi terhadap konsentrasi pada orang yang hidup di dataran tinggi dan tidak terdapat korelasi untuk dataran rendah (Tri, Ronald, \& Ray, 2018).

Penelitian ini dilakukan dengan menggunakan dosis moderat (75\%) 12 station dan 3 set selama 16 kali latihan. Dua sampel dalam penelitian ini terjadi ketidak seimbangan kemampuan tungkai. Kedua sampel memiliki kekuatan otot tungkai dibawah orang normal. Semestinya orang akan memiliki kekuatan tungkai setidaknya dua kali berat badannya. Dalam kasus ini kedua sampel tidak mampu untuk mengangkat beban yang sama dengan berat badannya.

Berdasarkan kejadian yang dicatat terhadap kedua orang ini khususnya EDW setiap kali melakukan latihan mengalami penurunan berat badan. Tercatat awal berat badan adalah 115, pada latihan yang ke 10 telah mengalami penurunan menjadi $98 \mathrm{~kg}$. penurunan pada latihan ke 16 lebih sedikit dan diakhir pertemuan turun menjadi $95 \mathrm{~kg}$. Sampel yang kedua berdasarkan catatan lapangan, timbangan berat badan tidak mengalami perubahan, bahkan sampai akhir latihan hanya mengalami penurunan $0.5 \mathrm{~kg}$.

Kedua member mengalami penurunan pada ukuran lemak (dada, perut dan paha), lingkar perut, panggul. Kedua subyek ini termasuk orang yang mengalami kelebihan berat badan, sehingga dengan latihan maka air yang ada dalam tubuh mengalami penyusutan. Hal berikutnya SHD mengalami peningkatan dalam 
ukuran lingkar lengan, paha dan betis. Penambahan lingkar ini kemungkinan disebabkan terjadinya hipertopi pada otot. Hasil penelitian ini sesuai dengan tiga hasil penelitian yang memberikan keterangan bahwa latihan dengan intensitas tinggi akan mempengaruhi komposisi tubuh (Su, LiQiang; et.all, 2019), (Feito, et.all, 2018), (Batrakoulis,et.all. 2018).

\section{SIMPULAN}

Pertama latihan berdampak penurunan berat terhadap satu subyek penelitian. Terdapat penurunan lemak pada semua pengukuran kadar lemak di tiga tempat pengukuran. Terjadi peningkatan lingkar pada lingkar lengan dan paha Sebagai efek hipertropi latihan.

Penelitian lebih lanjut perlu memperbanyak sampel agar dapat melihat konsistensi hasil penelitian. Perlu dilakukan pengukuran setiap setelah latihan untuk penelitian yang sama. Perlu adanya food recall agar dapat diketahui penyebab berhasil atau kurang berhasilnya dalam penurunan berat badan.

\section{DAFTAR RUJUKAN}

A. Alahmadi, M. (2014). High-intensity Interval Training and Obesity. Journal of Novel Physiotherapies, 4(3), 1-6. https://doi.org/10.4172/21657025.1000211

Aceves-Martins, M., Llauradó, E., Tarro, L., Solà, R., \& Giralt, M. (2016). Obesity-promoting factors in Mexican children and adolescents: Challenges and opportunities. Health Action. https://doi.org/10.3402/gha.v9.29625

Ahirwar, R., \& Mondal, P. R. (2019). Prevalence of obesity in India: A systematic review. Diabetes and Metabolic Syndrome: Clinical Research and Reviews, 13(1), 318-321. https://doi.org/10.1016/j.dsx.2018.08.032

Alaa Youssef Ahmed Ahmed Baioumi. (2019). Comparing Measures of Obesity: Waist Circumference, Waist-Hip, and Waist-Height Ratios. Nutrition in the Prevention and Treatment of Abdominal Obesity (Second Edition), 29-40. https://doi.org/https://doi.org/10.1016/B978-0-12-816093-0.00003-3

Batrakoulis, Alexios; Jamurtas, Athanasios Z; Georgakouli, Kalliopi; Dimitrios Draganidis; Deli, C. K. et al. (2018). High intensity, circuit-type integrated neuromuscular training alters energy balance and reduces body mass and fat in obese women: A 10-month training-detraining randomized controlled trial. PMID, 23;13(1). https://doi.org/10.1371/journal.pone.0202390

Bell, J. A., Hamer, M., Van Hees, V. T., Singh-Manoux, A., Kivimäki, M., \& 
Sabia, S. (2015). Healthy obesity and objective physical activity. American Journal of Clinical Nutrition, 102(2), 268-275. https://doi.org/10.3945/ajen.115.110924

Blüher, M. (2019). Obesity: global epidemiology and pathogenesis. Nature Reviews Endocrinology, 15, 288-298. https://doi.org/10.1038/s41574-0190176-8

Cerika, R. (2011). Kaitan antara Obesitas dan Aktivitas Fisik. Medikora.

Chang, C. K., Borer, K., \& Lin, P. J. (2017). Low-Carbohydrate-High-Fat Diet: Can it Help Exercise Performance? Journal of Human Kinetics. https://doi.org/10.1515/hukin-2017-0025

Dabas, A., \& Seth, A. (2018). Prevention and Management of Childhood Obesity. Indian Journal of Pediatrics, 85, 546-553. https://doi.org/10.1007/s12098018-2636-x

de Mello, A. H., Costa, A. B., Engel, J. D. G., \& Rezin, G. T. (2018). Mitochondrial dysfunction in obesity. Life Sciences, 192, 26-32. https://doi.org/10.1016/j.lfs.2017.11.019

Dias, K. A., Coombes, J. S., Green, D. J., Gomersall, S. R., Keating, S. E., Tjonna, A. E., ... Ingul, C. B. (2016). Effects of exercise intensity and nutrition advice on myocardial function in obese children and adolescents: A multicentre randomised controlled trial study protocol. BMJ Open. https://doi.org/10.1136/bmjopen-2015-010929

Dias, K. A., Ingul, C. B., Tjønna, A. E., Keating, S. E., Gomersall, S. R., Follestad, T., ... Coombes, J. S. (2018). Effect of High-Intensity Interval Training on Fitness, Fat Mass and Cardiometabolic Biomarkers in Children with Obesity: A Randomised Controlled Trial. Sports Medicine, 48, 733746. https://doi.org/10.1007/s40279-017-0777-0

Feito, Yuri; Heinrich, Katie M; Butcher, Scotty J; Poston, W. S. C. (2018). HighIntensity Functional Training (HIFT): Definition and Research Implications for Improved Fitness. MDPI, 6(3), 76. https://doi.org/10.3390/sports6030076

Fernandes, I. M. da C., Pinto, R. Z., Ferreira, P., \& Lira, F. S. (2018). Low back pain, obesity, and inflammatory markers: Exercise as potential treatment. Journal of Exercise Rehabilitation, 14(2), 167-174. https://doi.org/10.12965/jer.1836070.035

Ford, N. D., Patel, S. A., \& Narayan, K. M. V. (2017). Obesity in Low- and Middle-Income Countries: Burden, Drivers, and Emerging Challenges. Annual Review of Public Health, 38, 145-164. https://doi.org/10.1146/annurev-publhealth-031816-044604

González-Muniesa, P., Mártinez-González, M. A., Hu, F. B., Després, J. P., Matsuzawa, Y., Loos, R. J. F., ... Martinez, J. A. (2017). Obesity. Nature Reviews Disease Primers, 3, 17034. https://doi.org/10.1038/nrdp.2017.34 
Gorostegi-Anduaga, I., Corres, P., MartinezAguirre-Betolaza, A., Pérez-Asenjo, J., Aispuru, G. R., Fryer, S. M., \& Maldonado-Martín, S. (2018). Effects of different aerobic exercise programmes with nutritional intervention in sedentary adults with overweight/obesity and hypertension: EXERDIETHTA study. European Journal of Preventive Cardiology, 25(4). https://doi.org/10.1177/2047487317749956

Hilbert, A., Braehler, E., Schmidt, R., Lowe, B., Hauser, W., \& Zenger, M. (2015). Self-Compassion as a Resource in the Self-Stigma Process of Overweight and Obese Individuals. Obesity Facts. https://doi.org/10.1159/000438681

Kirwan, J. P., Sacks, J., \& Nieuwoudt, S. (2017). The essential role of exercise in the management of type 2 diabetes. Cleveland Clinic Journal of Medicine, 84(7), S15-S21. https://doi.org/10.3949/ccjm.84.s1.03

Lanigan, J., Tee, L., \& Brandreth, R. (2019). Childhood obesity. Medicine (United Kingdom), 47(3), P190-194. https://doi.org/10.1016/j.mpmed.2018.12.007

Magalhães, J. P., Júdice, P. B., Ribeiro, R., Andrade, R., Raposo, J., Dores, H., ... Sardinha, L. B. (2019). Effectiveness of high-intensity interval training combined with resistance training versus continuous moderate-intensity training combined with resistance training in patients with type 2 diabetes: A one-year randomized controlled trial. Diabetes, Obesity and Metabolism, 21(3), 550-559. https://doi.org/10.1111/dom.13551

Maïano, C., Lepage, G., Aimé, A., Bayard, C., Dansereau-Trahan, É., Granger, L., ... Morin, A. J. S. (2018). Perceived weight-related victimization and physical activity outcomes among adolescents with overweight and obesity: Indirect role of perceived physical abilities and fear of enacted stigma. Psychology of Sport and Exercise, 34, 70-78. https://doi.org/10.1016/j.psychsport.2017.08.007

Navalpotro, L., Regidor, E., Ortega, P., Martínez, D., Villanueva, R., \& Astasio, P. (2012). Area-based socioeconomic environment, obesity risk behaviours, area facilities and childhood overweight and obesity. Socioeconomic environment and childhood overweight. Preventive Medicine, 55(2), 102107. https://doi.org/10.1016/j.ypmed.2012.05.012

Ndanuko, R. N., Tapsell, L. C., Charlton, K. E., Neale, E. P., \& Batterham, M. J. (2016). Dietary patterns and blood pressure in adults: A systematic review and meta-analysis of randomized controlled trials. Advances in Nutrition, 7(1), 76-89. https://doi.org/10.3945/an.115.009753

Nigatu, Y. T., Reijneveld, S. A., De Jonge, P., Van Rossum, E., \& Bültmann, U. (2016). The combined effects of obesity, abdominal obesity and major depression/anxiety on health-related quality of life: The lifelines cohort study. PLoS ONE. https://doi.org/10.1371/journal.pone.0148871

Nystoriak, M. A., \& Bhatnagar, A. (2018). Cardiovascular Effects and Benefits of Exercise. Frontiers in Cardiovascular Medicine, 5, 135. 
https://doi.org/10.3389/fcvm.2018.00135

Obert, J., Pearlman, M., Obert, L., \& Chapin, S. (2017). Popular Weight Loss Strategies: a Review of Four Weight Loss Techniques. Current Gastroenterology Reports, 19, 61. https://doi.org/10.1007/s11894-017-06038

Quist, J. S., Rosenkilde, M., Gram, A. S., Blond, M. B., Holm-Petersen, D., Hjorth, M. F., ... Sjödin, A. (2019). Effects of Exercise Domain and Intensity on Sleep in Women and Men with Overweight and Obesity. Journal of Obesity, 12, 2019. https://doi.org/10.1155/2019/2189034

Roh, H. T., Cho, S. Y., \& So, W. Y. (2017). Obesity promotes oxidative stress and exacerbates blood-brain barrier disruption after high-intensity exercise. Journal of Sport and Health Science, 6(2), 225-230. https://doi.org/10.1016/j.jshs.2016.06.005

Shepherd, E., Gomersall, J. C., Tieu, J., Han, S., Crowther, C. A., \& Middleton, P. (2017). Combined diet and exercise interventions for preventing gestational diabetes mellitus. Cochrane Database of Systematic Reviews, (11), CD010443. https://doi.org/10.1002/14651858.CD010443.pub3

Spyridaki, E. C., Avgoustinaki, P. D., \& Margioris, A. N. (2016). Obesity, inflammation and cognition. Current Opinion in Behavioral Sciences, 9, 169-175. https://doi.org/10.1016/j.cobeha.2016.05.004

Staiano, A. E., Marker, A. M., Beyl, R. A., Hsia, D. S., Katzmarzyk, P. T., \& Newton, R. L. (2017). A randomized controlled trial of dance exergaming for exercise training in overweight and obese adolescent girls. Pediatric Obesity, 12(2), 120-128. https://doi.org/10.1111/ijpo.12117

Su, LiQiang; JinMei Fu; Sun, ShunLi; Zhao, GuangGao; Cheng, W. et al. (2019). Effects of HIIT and MICT on cardiovascular risk factors in adults with overweight and/or obesity: A meta-analysis. PLoS One; San Francisco, Vol. 14(I). https://doi.org/10.1371/journal.pone.0210644

Tri, I., Ronald, H., \& Ray, D. (2018). Aktivitas Fisik yang Tinggi Dapat Mengatasi Obesitas Sentral. Pendidikan Jasmani Olahraga. https://doi.org/10.17509/jpjo.v3i1.10461

Türk, Y., Theel, W., Kasteleyn, M. J., Franssen, F. M. E., Hiemstra, P. S., Rudolphus, A., ... Braunstahl, G. J. (2017). High intensity training in obesity: a Meta-analysis. Obesity Science and Practice, 3(3), 258-271. https://doi.org/10.1002/osp4.109

Vaamonde, J. G., \& Álvarez-Món, M. A. (2020). obesity and overweight. Medicine (Spain), 13(14), 767-776. https://doi.org/10.1016/j.med.2020.07.010

Van Vuuren, C. L., Wachter, G. G., Veenstra, R., Rijnhart, J. J. M., Van Der Wal, M. F., Chinapaw, M. J. M., \& Busch, V. (2019). Associations between 
overweight and mental health problems among adolescents, and the mediating role of victimization. BMC Public Health, 19, 612. https://doi.org/10.1186/s12889-019-6832-z

Verheggen, R. J. H. M., Maessen, M. F. H., Green, D. J., Hermus, A. R. M. M., Hopman, M. T. E., \& Thijssen, D. H. T. (2016). A systematic review and meta-analysis on the effects of exercise training versus hypocaloric diet: distinct effects on body weight and visceral adipose tissue. Obesity Reviews. https://doi.org/10.1111/obr.12406

Villablanca, P. A., Alegria, J. R., Mookadam, F., Holmes, D. R., Wright, R. S., \& Levine, J. A. (2015). Nonexercise activity thermogenesis in obesity management. Mayo Clinic Proceedings, 90(4), P509-519. https://doi.org/10.1016/j.mayocp.2015.02.001

Wang, Y., \& Lim, H. (2012). The global childhood obesity epidemic and the association between socio-economic status and childhood obesity. International Review of Psychiatry. https://doi.org/10.3109/09540261.2012.688195

Wewege, M., van den Berg, R., Ward, R. E., \& Keech, A. (2017). The effects of high-intensity interval training vs. moderate-intensity continuous training on body composition in overweight and obese adults: a systematic review and meta-analysis. Obesity Reviews, 18(6), 635-646. https://doi.org/10.1111/obr.12532

Zobel, E. H., Hansen, T. W., Rossing, P., \& von Scholten, B. J. (2016). Global Changes in Food Supply and the Obesity Epidemic. Current Obesity Reports, 5, 449-455. https://doi.org/10.1007/s13679-016-0233-8

Zulfiqar, A. C. (2014). Hubungan Indeks Massa Tubuh dengan Tingkat Kebugaran pada Mahasiswa Fakultas Kedokteran Angkatan 2011. Skripsi Fakultas Kedokteran Universitas Indonesia. 